Int. J. Electrochem. Sci., 11 (2016) $7527-7539$

\title{
A Novel Composite Obtained Through of Chemical Interaction of Zirconium (IV) Phosphated with Silver Hexacyanoferrate (III) for Voltammetric Detection of L-cysteine
}

\author{
Tayla Fernanda S. Da Silveira, Daniela S. Fernandes, Mariana de Souza Magossi, Priscila Fernanda \\ P. Barbosa, Tamires R. Souza, Maiara de Souza Magossi, Devaney R. Do Carmo*
}

Faculdade de Engenharia de Ilha Solteira, Universidade Estadual Paulista "Júlio de Mesquita Filho", Departamento de Física e Química, Av. Brasil Centro, 56, Ilha Solteira-SP, Brasil. CEP. 15.385-000. *E-mail: docarmo@dfq.feis.unesp.br

doi: $10.20964 / 2016.09 .65$

Received: 12 May 2016 / Accepted: 16 July 2016 / Published: 7 August 2016

A novel composite obtained from reaction of zirconium (IV) phosphated (ZrP) with $\mathrm{Ag}^{+}$and subsequent interaction of potassium hexacyanoferrate (III) $(\mathrm{ZrPAgH})$ was prepared and characterized by infrared spectroscopy (FTIR) and cyclic voltammetry. The graphite paste electrode modified with $\mathrm{ZrPAgH}$ exhibited a cyclic voltammogram with a redox couple with midpoint potential $E^{\theta^{\prime}}=0.70 \mathrm{~V}(v s$ $\left.\mathrm{Ag} / \mathrm{AgCl}_{(\text {sat. })}\right)$, attributed to the $\mathrm{Ag}^{\mathrm{I}}-\mathrm{CN}-\mathrm{Fe}^{\mathrm{II}} / \mathrm{Ag}^{\mathrm{I}}-\mathrm{CN}-\mathrm{Fe}^{\mathrm{III}}$ process $\left(40 \% w / w ; \mathrm{KNO}_{3} 1.0 \mathrm{~mol} \mathrm{~L}^{-1} ; v=20\right.$ $\mathrm{mV} \mathrm{s}^{-1}$ ). The graphite paste electrode modified with $\mathrm{ZrPAgH}$ can be used in the electrocatalytic oxidation of L-cysteine in a linear range from $1.0 \times 10^{-5} \mathrm{~mol} \mathrm{~L}^{-1}$ to $8.0 \times 10^{-5} \mathrm{~mol} \mathrm{~L}^{-1}(R=0.995)$ with detection limit of $1.02 \times 10^{-5} \mathrm{~mol} \mathrm{~L}^{-1}$ and amperometric sensitivity of $2.40 \mathrm{~mA} / \mathrm{mol} \mathrm{L}^{-1}$.

Keywords: Cyclic Voltammetry; Graphite Paste; L-cysteine; Silver Hexacyanoferrate (III); Zirconium Phosphated.

\section{$\underline{\text { FULL TEXT }}$}

(C) 2016 The Authors. Published by ESG (www.electrochemsci.org). This article is an open access article distributed under the terms and conditions of the Creative Commons Attribution license (http://creativecommons.org/licenses/by/4.0/). 